\title{
Influence of explant size, heat treatment, and variety on garlic (Allium sativum $L$ ) meristematic tissue growth
}

\author{
Asih K. Karjadi*, and Nazly Aswani \\ Indonesian Vegetable Research Institute. Jl. Tangkuban Perahu No. 157 Lembang - Bandung, West \\ Java
}

\begin{abstract}
Garlic (Allium sativum L) is one of genus Allium sp which propagated vegetatively. In vegetative propagation, virus is one of the major diseases. However, it has been approved that OYDV (Onion Yellow Dwarf Virus) can be eliminated through unconventional propagation techniques. The aim of this research was to evaluate the effect of explant, variety and heat treatment on the growth and development of explants dealing with virus elimination. The research was conducted on the IVEGRI tissue culture laboratory from May to September 2018. The research was designed using combination between explant types e.g. meristem (E1) and shoot tip (E2), heat treatment $\left(37^{\circ} \mathrm{C}\right)$ for 1 month, and varieties e.g. Lumbu Hijau (V1); Tawang Mangu (V2); Lumbu Putih (V3). The composition of media consisted of MS + MS vitamine + Sucrose $30 \mathrm{~g} \mathrm{~L}^{-1}+$ IAA $2 \mathrm{mg} \mathrm{L}^{-1}+$ Kinetin $2 \mathrm{mgL}^{-1}+\mathrm{GA}_{3} 0.01 \mathrm{mgL}^{-1}+\mathrm{Gel}$ gro $2 \mathrm{gL}^{-1}, \mathrm{pH} 5.7$ were used as media growth. The results concluded that explant size, heat treatment and varieties affected percentage of proliferation. The bigger the explant size used, the higher growth percentage resulted. From the average number of shoots, leaves and roots, it also suggested that explant type and varieties affected the explant growth and development. Moreover, it was shown that the culture contamination on 10 WAP ranged from $20 \%$ to $55 \%$ which generally caused by bacteria. The results of virus testing OYDV on plantlets using DAS ELISA Serology technique showed that the infected cultures ranged from $22.22 \%$ to $60 \%$.
\end{abstract}

\section{Introduction}

The Garlic (Allium sativum L) belongs to genus Allium which is propagated vegetatively. Currently garlic propagation can be carried out through unconventional or micropropagation method by tissue culture techniques. Goal of unconventional propagation is to improve quality or simply propagate plant organ $[1,2,3]$.

Viral systemic disease is one of the important diseases that must be eliminated from the plant that propagated vegetatively. Research of Walkey et al. [4] and Fayek et al. [5], indicated that this systemic disease infection can reduce production between $2-50 \%$. The

* Corresponding author: asihkk@yahoo.com 
viral disease that has been infested will continue to be carried from generation to generation. An alternative way to remove/eliminate viruses can be performed by heat treatment from a donor explant or planting different type of explant such as meristematic tissue.

Tissue culture technique (unconventional multiplication) is known as a technique to grow cells, tissues, organs into perfect plants in artificial media which is carried out in vitro (aseptically). The growth media must consist of macro and micro nutrients, vitamins and other nutrients such as carbohydrate sources, and growth regulators [6,7,8]. The propagation of garlic in an unconventional way through tissue culture techniques is influenced by several factors including genotype, explant/ the source of donor explant, explant size and explant pre-treatment $[9,10,11]$.

The aim of this research was to evaluate the effect of explant type, variety and heat treatment on the growth and development of explants to produce disease-free plants.

\section{Materials and methods}

The research was conducted at the IVEGRI Tissue Culture Laboratory from May to September 2018. Explants were sampled from the selected varieties of Lumbu Hijau (V1), Tawang mangu (V2) and Lumbu Putih (V3) which were previously infected with the OYDV virus. Subsequently, the explants were subjected to heat treatment $\left(35^{\circ} \mathrm{C}\right)$ for 1 month (P1) and non-heat treatment (P2). The explant types were categorized as meristem (E1) and Shoot tip (E2). Growth medium of MS + MS vitamin + Sucrose $30 \mathrm{~g} \mathrm{~L}^{-1}+$ IAA 2 $\mathrm{mg} \mathrm{L}^{-1}+$ Kinetin $2 \mathrm{mg} \mathrm{L}^{-1}+\mathrm{GA}_{3} 0.01 \mathrm{mg} \mathrm{L}^{-1}+\mathrm{Gel}$ gro $2 \mathrm{~g} \mathrm{~L}^{-1}, \mathrm{pH} 5.7$ was used to grow the explants. The research stages were carried out as follows:

1. Sterilized garlic explants were peeled after heat treatment. The shoots were taken out of the cloves, washed in a detergent solution and rinsed again with distilled water for 2-3 times, then dipped in $70 \%$ alcohol, soaked in $25 \%$ chlorox solution for 15 minutes, rinsed again with sterile distilled water for 3-5 times and finally transferred to sterilized petridishes.

2. Explants were then transferred in a sterile LAFC (Laminer Airflow Cabinet), planted in a $50 \times 150 \mathrm{~mm}$ test tube with a media volume of 5- $8 \mathrm{ml}$. Cultures were incubated in the culture room with a temperature of $22-24^{\circ} \mathrm{C}$, photo period 16 hours light, 8 hours dark.

3. As much as 20 test tubes were planted for each treatment The study did not use a statistical design, observations were made visually on the parameters \% proliferation, $\%$ contaminated, average number of leaves, roots per plantlet and percentage of OYDV infected plants..

\section{Results and discussion}

The observation on growth and development of 3 garlic varieties and percentage of infected virus were obtained at 10 WAP. Explants of three garlic varieties, that were Lumbu Hijau, Tawang Mangu and Lumbu Putih showed percentage range of 43 - 80\% (Figure 1) at 10 WAP. Several main factors for successful meristematic tissue proliferation, namely (a) explant sources, (b) growth media and ZPT, (c) physical environment and (d) regeneration systems $[12,13,14]$. In addition to those factors, plant genotype also affects successful proliferation rate $[15,16]$. 


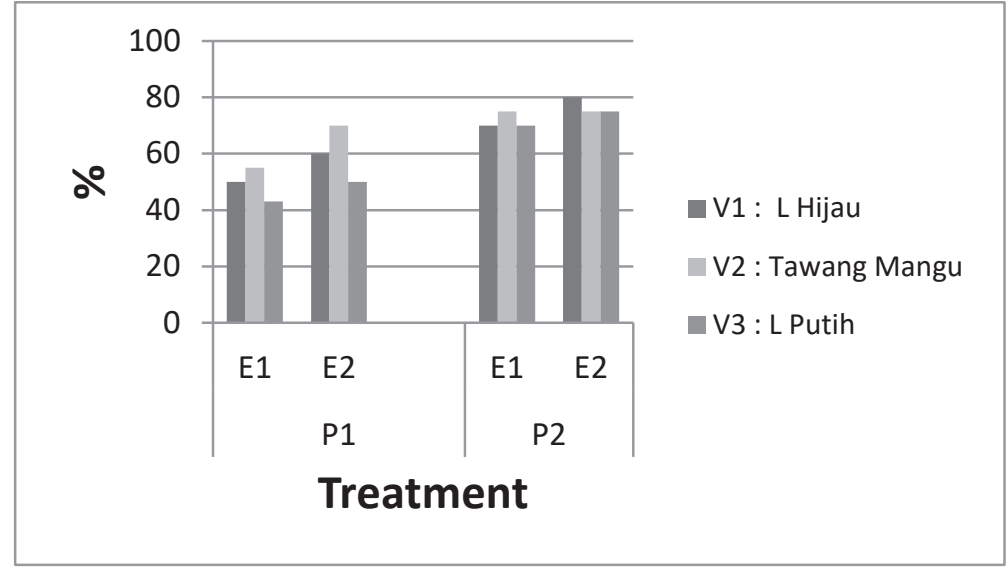

Fig. 1. Percentage of explant proliferation at $10 \mathrm{WAP}$ $\mathrm{E} 1=$ Meristem, E2 $=$ Shoot tip, P1 $=$ Heat treatment, P2 = non-heat treatment

In general, each plant genotype responds differently to meristematic tissue treatment and media composition [17,18]. According to Bhojwani and Datu [19], meristematic tissue explant can grow and develop/ proliferate because the explant has 1-2 primordial leaves that can be supply auxin and cytokinins for supporting its growth.

According to George and Sherington [20] plant propagation through tissue culture has several advantages, e.g. (1) it only use a small size of explant which avoid the whole plant destruction, (2) the growth condition is aseptic and controlled, (3) provide a faster propagation, (4) can produce disease-free seeds from infected plants, (5) requires a relatively small space to produce large numbers of plantlets

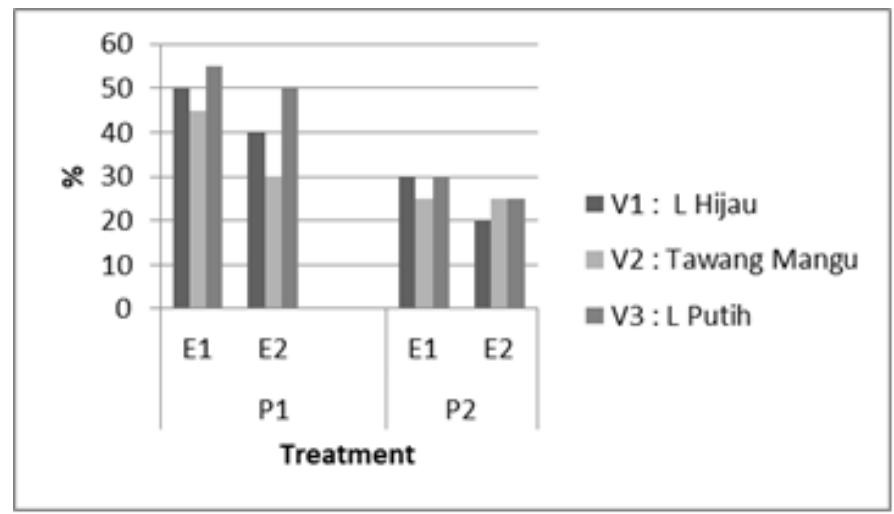

Fig. 2 . Percentage of explant contamination at $10 \mathrm{WAP}$

$\mathrm{E} 1=$ Meristem, $\mathrm{E} 2=$ Shoot tip, $\mathrm{P} 1=$ Heat treatment, $\mathrm{P} 2=$ non-heat treatment

In tissue culture technique, contamination-free explant is a necessary prerequisite. Fungi and bacteria can cause explant contaminated. These contaminant agents will grow and develop faster in the culture media which contains sugars, vitamins and minerals. Contaminated explants will totally eventually do not develop. At the multiplication process of tissue culture techniques, contamination is obstacles that can be thwart the growth and development of the explant. 
Percentage of contaminated cultures at the age of 10 WAP ranged between $20-35 \%$ (Figure 2) where heat treatment showed higher contamination compared to non-heat treatment. Whereas in each treatment, contamination on meristematic explant was higher than shoot tip explant. This observation suggested that varieties, heat treatment, explant size had an effect on the percentage of contamination at 10 WAP. According to Gunawan [21], Armini et al. [22], and Haider et al. [23], sources of contaminants are generally carried from explant donors either on the surface or within (endogenous) the explant tissue.

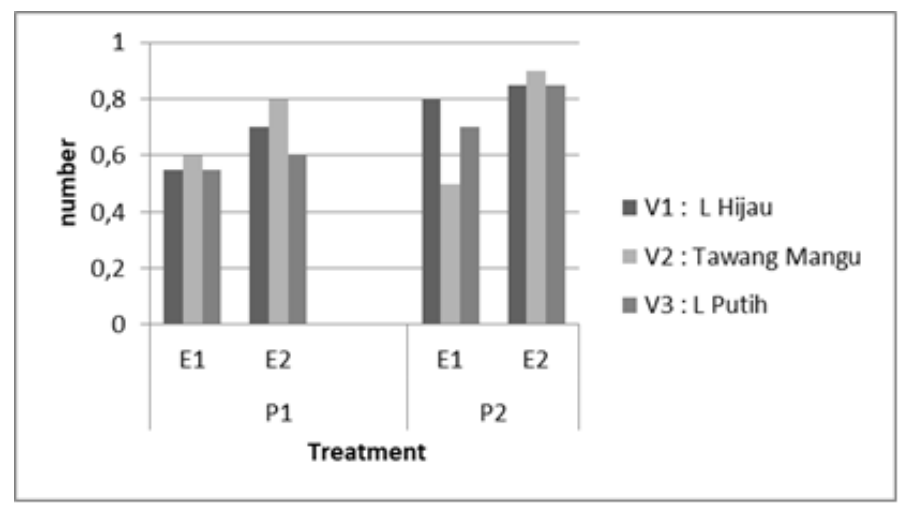

Fig. 3. The average numbers of shoot at $10 \mathrm{WAP}$

$\mathrm{E} 1=$ Meristem, $\mathrm{E} 2=$ Shoot tip, $\mathrm{P} 1=$ Heat treatment, $\mathrm{P} 2=$ non-heat treatment

The average number of shoots ranged between 0.5 - 0.9 (Figure 3). Some explants failed to form shoots, the tissue only swelled and turned green. This visual observation noticed that the varieties, heat treatment and explant type had no different effects on the average number of shoots.

However, it can be seen that the combination of varieties, explant type and heat treatment affected the number of shoots grew. Whereas the explant shoot tip is always better than the explant meristem, and the heat treatment hindered the shoot growth. The formation of shoot and its growth in vitro is influenced by various factors [24,25], including the type and composition of the media, the origin of the explant. In addition, it is also influenced by various complex factors, namely (a) genetic factors, (b) medium :macro, micro elements as well as sources of carbohydrates and other supplements, (c) physical factors such as light, temperature, media $\mathrm{pH}$, concentrations of $\mathrm{O}_{2}$ and $\mathrm{CO}_{2}$ and (d) growth regulators such as amino acids and vitamins. 


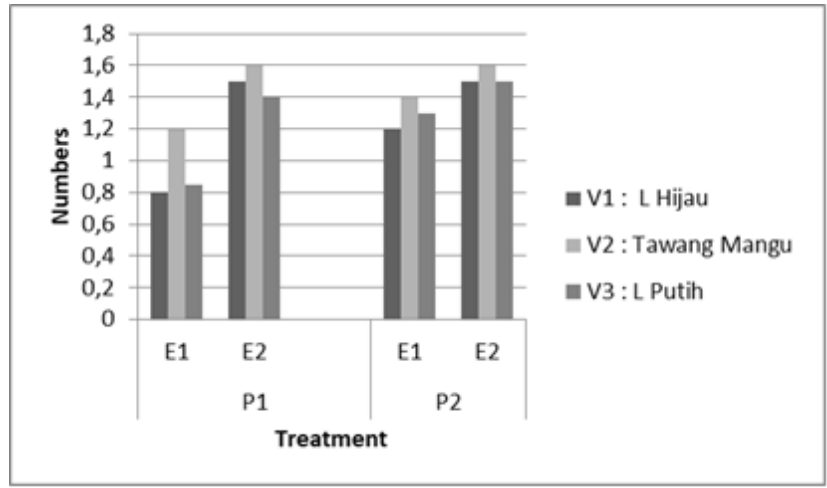

Fig . 4. The average numbers of leaves at $10 \mathrm{WAP}$

$\mathrm{E} 1=$ Meristem, $\mathrm{E} 2=$ Shoot tip, $\mathrm{P} 1=$ Heat treatment, $\mathrm{P} 2=$ non- heat treatment

The average number of leaves ranged between 0.8 - 1.6 (Figure 4) where meristematic tissue (E1) showed a smaller number than shoot tip (E2) in either heat or non-heat treatment. Meanwhile the heat treatment resulted in a smaller number of leaves than without heat treatment as well as for the explant size

In propagation through tissue culture, the response of explants varies depending on the components of the culture conditions such as culture media components and its additional nutrition/elements or type of explant such as size and the source of explant. It needs a combination of two or more components which is simultaneously or partially applied to increase the response of the explant [2,26,27].

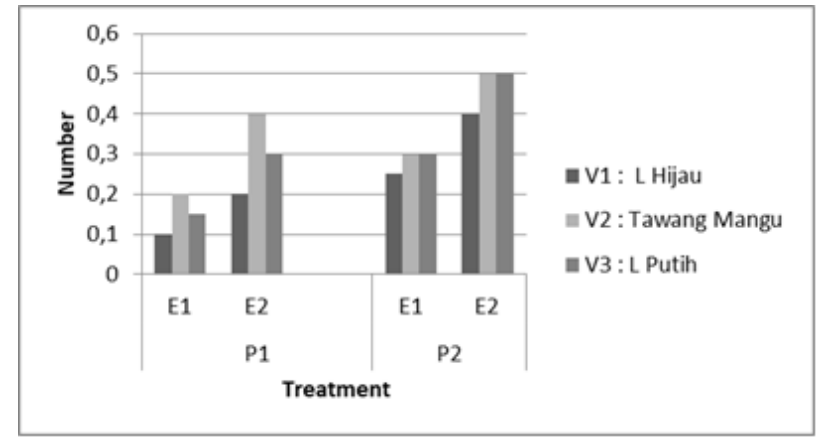

Fig. 5. The average numbers of roots at $10 \mathrm{WAP}$

$\mathrm{E} 1=$ Meristem, $\mathrm{E} 2=$ Shoot tip, $\mathrm{P} 1=$ Heat treatment, $\mathrm{P} 2=$ non-heat treatment

The average number of roots ranged between $0.1-0.5$ (Figure 5). Generally, heat treatment resulted a smaller number than non-heat treatment, although variety Tawangmangu Baru showed a higher number compared to other varieties in the heat treatment for both meristematic tissue and shoot tip. In visual observation noticed that root growth was stunted. According to Haider et al. [23] and George et al. [28], a successful development and application of plant tissue culture with various treatments is strongly influenced by the culture media and the level of suitability with the explant material to be cultured.

According to Kapoor et al. [27] and Noiton et al. 29] concluded that increasing root growth from plantlets can be achieved by giving sub-culture treatment to the new growing media. This treatment will facilitate the explant to root yet also causes a decrease in the regeneration and growth ability of the plantlet. 
Table 1. The percentage plantlet of 3 varieties infected Onion Yellow Dwarf Virus (OYDV)

\begin{tabular}{|c|c|c|c|c|c|c|c|c|c|c|c|c|}
\hline \multirow[b]{3}{*}{ Variety } & \multicolumn{6}{|c|}{ P1 = Heat treatment } & \multicolumn{6}{|c|}{$\mathbf{P} 2=$ Non Heat treatment } \\
\hline & \multicolumn{3}{|c|}{ E1 $=$ Meristem } & \multicolumn{3}{|c|}{ E2 $=$ Shoot tip } & \multicolumn{3}{|c|}{ E1 $=$ Meristem } & \multicolumn{3}{|c|}{ E2 = Shoot tip } \\
\hline & $\mathbf{A}$ & B & $\mathbf{C}$ & $\mathbf{A}$ & B & $\mathrm{C}$ & $\mathbf{A}$ & B & $\mathbf{C}$ & $\mathbf{A}$ & B & $\mathbf{C}$ \\
\hline $\begin{array}{c}\text { V1 = } \\
\text { L Hijau }\end{array}$ & 10 & 2 & $\begin{array}{c}2 / 10= \\
20\end{array}$ & 12 & 5 & $\begin{array}{l}5 / 12= \\
41.67\end{array}$ & 14 & 6 & $\begin{array}{c}6 / 14= \\
42.86\end{array}$ & 16 & 8 & $8 / 16=50$ \\
\hline $\begin{array}{c}\mathrm{V} 2= \\
\text { Tawang } \\
\text { Mangu }\end{array}$ & 11 & 5 & $\begin{array}{l}5 / 11= \\
45.46\end{array}$ & 14 & 6 & $\begin{array}{l}6 / 14= \\
42.86\end{array}$ & 15 & 7 & $\begin{array}{l}7 / 15= \\
46.67\end{array}$ & 15 & 9 & $9 / 15=60$ \\
\hline $\begin{array}{c}\mathrm{V} 3= \\
\mathrm{L} \text { putih }\end{array}$ & 9 & 2 & $\begin{array}{l}2 / 9= \\
22.22\end{array}$ & 10 & 4 & $4 / 10=40$ & 14 & 5 & $\begin{array}{l}5 / 14= \\
35.71\end{array}$ & 15 & 8 & $\begin{array}{l}8 / 15= \\
53.33\end{array}$ \\
\hline
\end{tabular}

Note: $\mathrm{A}=$ Number of plantlet $; \mathrm{B}=$ Number infected $; \mathrm{C}=$ Percentage of infected $(\%)$

The percentage of plantlets infected with OYDV (Onion Yellow Dwarf Virus) was calculated from the total number of fully grown or normal plantlets. Where the percentage of the number infected divided by the total plantlets grew normally. Table 1 showed the percentage of cultures still infected with OYDV that ranged between $22.22-60 \%$ (Table 1). Elisa test resulted a high percentage of virus infection; this indicates that heat treatment and the type of the explant source were not yet optimum for the elimination of OYDV virus in 3 garlic varieties. According to Zaitlin and Palukautis [30] and Sharma et al. [31], if the virus is still detected, this indicates that the heating treatment and size of the explant is not optimal so that the explant initiation for regeneration of virus particles is still carried away.

According to Sharma et al. [31], heating treatment with a temperature range of 35 $40^{\circ} \mathrm{C}$ will reduce the virus concentration and even eliminate systemic diseases. The level of tolerance and survival of plants with increasing temperature treatment and treatment time are limiting factors in a successful heat treatment $[32,33,34]$.

The successful virus elimination is also influenced by several things such as the size of the meristem tip [35,36], virus concentration in plant tissue [25], plant genotype, type of growth hormone used in in vitro culture [35] and elimination method [19,37].

\section{Conclusions}

This study indicated that explant size, heat treatment and variety affected the proliferation, average numbers of shoot, leaves, and roots of plantlets. Culture contamination ranged from $20-51 \%$, were generally caused by bacteria. Virus test of OYDV on plantlet of 3 garlic varieties using DAS ELISA technique showed that the infected ranged between $22.22-60$ $\%$.

\section{Reference}

1. M.M.A. El-Nil, Plant Sci. Letter. 9, 254 - 264 (1977)

2. D. Kamstaityte, S. Stanys. Acta. Univ. Latv. Biol. 676, 173 - 176 (2004)

3. I. Gull, A. Noreen, M.S. Aslam, M.A. Ather, Pakistan J. Biochem. Mol. Biol. 47, 121$124(2014)$

4. D.G.A. Walkey, M.J.W. Weleb, C.J. Bold, A. Miller, J. Hort. Sci. 62, 211-219 (1987)

5. M.A. Fayek, A.H. Jomaa, A.B.A. Shalabby, M.M. Dhaher, In Vitro. 4, 1-11 (2009)

6. G.O.M. RA, K. Ojima, Cell Exp. Res. 50, 151 - 158 (1968)

7. N. Seif El, H. Gadel, Z. Kaseim, A. Yasser, M.M. Moustafa, S.Z. Asma, J. Hort. Sci. Ornamental. 3, 2, 115 -129 (2011)

8. S.N. Parisa, K.H. Mina, D. Akbar, K. Siamah, J. Crop. PROT. 4, 4, 533 - 543 (2015)

9. J. Buiteveld, M.J. Creemeer, Plant. Sci. 100, 2003-2010 (1994) 
10. C. Eady, R.C. Bulter, Y. Suo, Plant. Cell. Report. 18, 111-116 (1998)

11. S. Zheng, B. Henken, E. Jacobsen, F.A. Krens, C. Klik, Tissue Organ Cult. 53, 99 -105 (1998)

12. G.A. Wattimena, M. Nurhayati, N.M. Armini, A. Purwito, D. Efendi, B.S. Purwoko N. Khumaida, Bioteknologi dalam pemuliaan tanaman (IPB Press, Bogor, 2011)

13. D. Dinarti, A. Purwito, D.S. Anas, R. Iis, J. Ilmu Pertan. Indonesia. 32-37 (2008)

14. G. Dugssa, T. Feyissa, J. Sci. 34, 1, 17 - 28 (2011)

15. B. Nesi, D. Trinchello, S. Lazzereschi, A. Grassutti, Horticulture Sci. 44, 1, 217- 219 (2009)

16. Farhadi, P. Njaber, M.A. Alireza, A.S. Saeideh. Scientia Horticulture. 218, $80-86$ (2017)

17. M.E. Haque, J.W. Mainsfied. Plant Cell Tissue Org. Cult. 78, 217 - 223 (2004)

18. Luc, M.P. Bridgen, Plant Sci. 116, 205-212 (1996)

19. S.S. Bhojwani, P.K. Datu, Production of virus free plants by tissue culture, Plant Tissue Culture. 227-243 (2013)

20. E.F. George, P.D. Sherington, Plant propagatin by tissue culture (Excegetic. Ltd. England, 1984)

21. L.W. Gunawan, Teknik kultur jaringan tumbuhan (Lab. Kultur jaringan, PAU, Bioteknologi IPB, Bogor, 1987)

22. G.A. Armini, Wattimena, L.W. Gunawan, Bioteknologi Tanaman, p. 12-48 (PAU, Bioteknologi IPB, Bogor, 1992)

23. S. Haider, M. Hossain, S. Rahman, S. Sultan, T. Quddus, M. Chakraborti, A. Haque, M. Shakriar, M. Haque, Br. Biotechnol. J. 8, 1- 12 (2015)

24. Y. Shen, M.E. Kane, J. Chen, In vitro Cell. Dev. Biol. Plant. 44, 282 -288 (2008)

25. D. Pramesh, V.K. Baranwal, J. Hort Sci. Biotech. 90. 2, 180-186 (2015)

26. R. Roksana, M.F Alam, R. Islam, M.M. Hossain, Plant Tissue Cult. 12, 11-17 (2002)

27. R. Kapoor, S.A. Nasrin, Mahmooduzzafar, A. Mujib. J. Ecobiotechnology. 3, 12, 14-17 (2011)

28. E.F. George, M.A. Hall, G.J. de Klerk 2008, Plant propgation by tissue culture, the background, 13rd, p. 274 - 338 (Springer, Netherlands, 2008)

29. D. Noiton, J.H. Vine, M.G. Mullins, Plant Growth Regul. 11, 337-383 (1992)

30. M. Zaitlin, P. Palukautis, Am. Dev. Phytophatol. 38, 17-143 (2000)

31. S. Sharma, S.B. Singh, G. Rani, A.A. Zaidi, V. Hallan, A. Nagpal, G.S. Virk, J. Cent. Eur. Agric. 8, 1, 1-8 (2007)

32. H. Lazoya-Sldana, O. Merlinlara, Am Pot J. 61, 737-739 (1984)

33. A.C.T. Fajardo, A.N. Dusi, P.O. Resende, J.A. Buso, Hort. Brasifeire. Brasicia. 18, 3, $192(2000)$

34. D.C. Manjunathagowda, J. Gopal, R. Archana, K.R. Asiya, Int. J. Curr. Microbiol App. Sci. 6, 6, 2446-2456 (2017)

35. M. Ashyani, M. Kharrazi, A. Sharifi, M. Mehrvar, J. Biol . Environ Sci. 6, 17, 175-180 (2012)

36. G.J.H. Hu, L.P. Wang, H.J. Hu, G.P. Wang, Crop protection. 37, 20-26 (2012)

37. M.N. Hassan, M.S. Haque, M.M. Hassan, M.S. Haque, J. Bangladesh Agri. Univ. 12, $1-6(2014)$ 